FOLIA POMERANAE UNIVERSITATIS TECHNOLOGIAE STETINENSIS

Folia Pomer. Univ. Technol. Stetin., Oeconomica 2017, 335(87)2, 245-260

Marzena RYDZEWSKA-WŁODARCZYK

\title{
POLSKA RAMA KWALIFIKACJI JAKO ELEMENT ZINTEGROWANEGO SYSTEMU KWALIFIKACJI W POLSCE
}

\author{
THE POLISH QUALIFICATIONS FRAMEWORK AS ELEMENT \\ OF THE INTEGRATED QUALIFICATIONS SYSTEM IN POLAND
}

Zakład Ekonomii i Rachunkowości, Zachodniopomorski Uniwersytet Technologiczny w Szczecinie ul. Żołnierska 47, 71-210 Szczecin, e-mail: mrydzewska@zut.edu.pl

\begin{abstract}
Summary. Establishing the functioning qualifications concerning the year of common principles in 2015 in various areas of the education was a next stage of the construction process in Poland of the Integrated Qualifications System (IQS). The main tool of this system is Polish Qualifications Framework (PQF). It is used for the identification of getting skill levels both in an educational system formal, as well as informal and as a result of the unofficial learning, and because of that lets for comparing qualifications conferred in educational systems and the higher education and apart from them. PQF has eight levels of qualifications, as does the European Qualifications Framework. Each PQF level is described by general statements, known as descriptors, characterising the requirements for knowledge, skills and social competence, which must be fulfilled by persons having a qualification at a given level. The paper presents the results of research aimed at getting to know the structure and applications of PQF. Universal characterizations of levels PQF were discussed on the example of characterizations referring to classifications get as part of the higher education, however, characterizations of the PQF second degree were discussed on the example of the description of the effects of the learning typical of the area of the education in social sciences.
\end{abstract}

Słowa kluczowe: charakterystyki poziomów PRK, kwalifikacje, polska rama kwalifikacji (PRK), system kwalifikacji, Zintegrowany System Kwalifikacji (ZSK).

Key words: descriptors PQF, Polish Qualifications Framework (PQF), Integrated Qualifications System (IQS), qualifications, qualifications system.

\section{WSTĘP}

Dynamiczne zmiany zachodzące w gospodarce i w sferze społecznej determinują zjawiska występujące na rynku pracy i skłaniają jego uczestników do zadawania pytań:

1. Czy wiedza i umiejętności, które posiadają kandydaci do pracy i pracownicy są wystarczające i jak je należy dokumentować?

2. W jaki sposób pracodawcy powinni oceniać, weryfikować i porównywać kompetencje kandydatów do pracy i pracowników?

Pytania o oczekiwany i zadowalający poziom kompetencji i kwalifikacji powstają też w kontekście nieustających zmian w organizacji i uprzemysławianiu procesów pracy, jak również pod wpływem nowych koncepcji zarządzania organizacjami i zespołami. Problematyka ta 
ma również bezpośredni związek z ideą kształcenia ustawicznego (ang. lifelong learning) ${ }^{1}$. Koncepcja lifelong learning, rozpropagowana w Europie w wyniku przyjęcia strategii lizbońskiej ${ }^{2}$ i towarzyszącym jej dokumentom i programom ${ }^{3}$, jest związana z rozwojem indywidualnym i społecznym człowieka, bez względu na miejsce, czas i sposób zdobywania wiedzy i nowych umiejętności. Rozwój ten może następować zarówno w ramach kształcenia w systemie formalnym, jak i w edukacji nieformalnej i pozaformalnej. Istotny wkład w promowanie koncepcji edukacji ustawicznej miała Rada Unii Europejskiej.

Dokonująca się w Polsce modernizacja systemu kwalifikacji trwa od lat 90. XX wieku i jest jednym z elementów realizacji przyjętej przez rząd RP i szerzej opisanej w krajowych dokumentach strategicznych polityki uczenia się przez całe życie ${ }^{4}$. Działania dotyczące porządkowania krajowego systemu kwalifikacji odzwierciedlają zmiany zachodzące w tym obszarze w Europie $^{5}$. Koncepcja kształcenia ustawicznego pozostaje bowiem w ścisłym związku z potrzebą budowy zintegrowanych spójnych systemów kwalifikacji służących rozpoznawaniu i certyfikowaniu kompetencji zawodowych zdobywanych przez osoby uczące się w ramach edukacji formalnej, pozaformalnej i nieformalnej.

Prace nad polską ramą kwalifikacji trwają w Polsce od wielu lat. Podstawy prawne tej koncepcji stanowił przyjęty przez Radę Ministrów krajowy program reform na lata 2005-2008, w którym wśród zadań do realizacji wskazane zostało opracowanie i wdrożenie spójnych z europejską ramą kwalifikacji krajowych ram kwalifikacji $(\mathrm{KRK})^{6}$.

\footnotetext{
${ }^{1}$ Kształcenie ustawiczne nazywane też edukacją permanentną, całożyciową, kształceniem permanentnym lub nieskończonym; odnosi się do trwającego przez całe życie procesu ciągłego doskonalenia, odnawiania, rozwijania i nabywania nowych kwalifikacji ogólnych i zawodowych jednostki - zob. m.in. Rydzewska-Włodarczyk (2006); Wiktorowicz (2010); Wiatrowski (2012); Grotowska-Leder (2014). Komisja Europejska termin ten odnosi do podejmowanych przez całe życie wszelkich form nauki, mających na celu doskonalenie, pogłębianie wiedzy, umiejętności i kompetencji z perspektywy osobistej (indywidualnej), obywatelskiej, społecznej i / lub zawodowej zob. Making a European... (2001). Problematyka ta jest szczegółowo omawiana zarówno w literaturze krajowej, jak i zagranicznej.

2 Po upływie okresu realizacji strategii lizbońskiej zdecydowano, że dalsza polityka rozwoju UE wymaga kolejnej wieloletniej strategii. Sukcesorką strategii lizbońskiej stała się uchwalona w czerwcu 2010 r. „Europa 2020. Strategia na rzecz inteligentnego i zrównoważonego rozwoju sprzyjającego społecznemu włączeniu” - zob. Europe 2020. A strategy for smart, sustainable... (2010).

${ }^{3} \mathrm{Na}$ poziomie regionalnym były to przykładowo: Edukacja i szkolenia 2010 (2012); Rezolucja Rady w sprawie odnowionej europejskiej agendy... (2011).

4 Spośród licznych dokumentów z tego zakresu wymienić należy Krajowy Program Reform na rzecz realizacji Strategii „Europa 2020” (2011) i kolejne jego aktualizacje.

${ }^{5} \mathrm{Na}$ europejskie standardy edukacyjne składają się promowane w UE idee: 1. Edukacja przez całe życie (lifelong learning) - zaleca ustawiczne kształcenie kompetencji podmiotowych i zdobywanie wiedzy (Rozporządzenie Rady z dnia 27 czerwca 2002 r. w sprawie uczenia się...); 2. Kompetencje kluczowe dla poszczególnych stanowisk pracy, których kształcenie należy prowadzić, opierając edukację na efektach kształcenia: wiedzy, umiejętnościach i kompetencjach społecznych oraz personalnych (Zalecenie Parlamentu Europejskiego i Rady Unii Europejskiej z dnia 18 grudnia 2006 r. w sprawie kompetencji...); 3. Europejskie i krajowe ramy kwalifikacji, które opisują rodzaje kwalifikacji, będące wynikiem kształcenia na różnych poziomach edukacji; ramy te służą porównaniu kwalifikacji na terenie UE, ułatwiając mobilność pracowników i wspierając związek edukacji z rynkiem pracy (Zalecenie Parlamentu Europejskiego i Rady z dnia 23 kwietnia 2008 r. w sprawie ustanowienia Europejskich Ram Kwalifikacji...). Dokumenty te są źródłem zmian modelu kształcenia w Europie.

${ }^{6}$ Zapisy dotyczące budowy KRK ujęto w kolejnych aktualizacjach krajowego programu reform. Budowę KRK i systemu kwalifikacji uwzględniły też: strategia rozwoju kraju na lata 2007-2015 i strategia rozwoju edukacji na lata 2007-2013. Budowa polskiej ramy kwalifikacji została też zapowiedziana w strategii rozwoju kraju na 2020 r., w której widnieje zapis o odniesieniu do europejskiej ramy kwalifikacji za pośrednictwem PRK kwalifikacji uzyskiwanych przez osoby uczące się w Polsce. Z kolei jednym z założeń projektu strategii rozwoju kapitału ludzkiego jest idea stanowiąca, że stworzenie krajowego systemu kwalifikacji, jako części europejskiej przestrzeni uczenia się przez całe życie, umożliwi lepszą porównywalność kwalifikacji oraz zwiększy możliwości potwierdzania kompetencji uzyskanych w ramach edukacji pozaformalnej i w drodze uczenia się nieformalnego zob. Raport referencyjny... (2015).
} 
Od 1 października 2012 r. KRK stały się obowiązkową podstawą tworzenia programów kształcenia na uczelniach ${ }^{7}$. Podstawą opracowania programów kształcenia dla cykli kształcenia rozpoczynających się od roku akademickiego 2017/2018 będzie polska rama kwalifikacji (PRK).

Celem artykułu jest omówienie PRK jako głównego instrumentu polskiego systemu kwalifikacji.

\section{MATERIAŁ I METODY}

W artykule został scharakteryzowany funkcjonujący w Polsce system kwalifikacji, a w szczególności tworzące go instrumenty: polska rama kwalifikacji i zintegrowany rejestr kwalifikacji. Materiał badawczy stanowiła literatura krajowa i zagraniczna z tego zakresu, akty prawne regulujące problemy stanowiące przedmiot badań, dokumenty i materiały informacyjne zamieszczone na portalach instytucji edukacyjnych, w tym w szczególności odnoszące się do kwalifikacji nadawanych przez szkoły wyższe. Analizowany w toku badań materiał stanowiły charakterystyki uniwersalne (pierwszego stopnia) i typowe (drugiego stopnia) określone dla poziomu 6-8 PRK. Zaprezentowane w opracowaniu wyniki analizy w szczególności charakteryzują efekty uczenia się absolwentów studiów licencjackich.

Opracowanie artykułu poprzedziły badania literaturowe nad zagadnieniem opracowania i wdrażania w Polsce i w Europie ram kwalifikacji, nadawania kwalifikacji oraz sposobu ich opisu na podstawie efektów kształcenia i uczenia się. Przeprowadzona w toku badań analiza źródeł literaturowych i norm zawartych w aktach prawnych miała na celu poznanie istoty, przesłanek wdrożenia, zasad budowy polskiej ramy kwalifikacji, jak również funkcjonowania w Polsce systemu kwalifikacji. W procesie badawczym zastosowano też metody indukcji i dedukcji.

\section{PRZESŁANKI BUDOWY W POLSCE ZINTEGROWANEGO SYSTEMU KWALIFIKACJI}

Powszechnie przyjmuje się, że główne źródło konkurencyjności w globalnej gospodarce stanowi kapitał intelektualny (Wierżyński i Stankiewicz 2002; Haffer 2003; Rogowski 2006; Griffin 2007; Rosińska 2007; Walczak 2010; Bombiak 2013). Jego rozwój i wzrost wartości jest więc jednym z celów współczesnych organizacji. Mimo że pojęcie kapitału intelektualnego jest niejednoznacznie i często odmiennie definiowane, warto przypomnieć, że tworzą go w szczególności kompetencje pracowników, które umożliwiają im podjęcie i pełnienie określonych funkcji w organizacji. Kompetencje te są więc przedmiotem oceny, szczególnie w procesie rekrutacji i selekcji, jak również w trakcie oceniania pracowników. W procesach tych istotne znaczenie przypisuje się kompetencjom potwierdzonym uznawanymi dokumentami, takimi jak świadectwa, dyplomy, certyfikaty. Jakość i wiarygodność tych dokumentów zapewniać powinien ujednolicony, znormalizowany system kwalifikacji. System ten powinien ponadto ułatwiać porównywalność kwalifikacji uzyskanych w ramach różnych systemów

\footnotetext{
7 Obowiązek taki wprowadzono w 2011 r. - zob. Ustawa z dnia 18 marca 2011 r. o zmianie ustawy Prawo o szkolnictwie wyższym, ustawy o stopniach naukowych i tytule naukowym oraz o stopniach i tytule w zakresie sztuki oraz o zmianie niektórych innych ustaw.
} 
szkolnictwa i certyfikacji kwalifikacji, w tym stwarzać podstawy do nadawania kwalifikacji na bazie efektów uczenia się uzyskanych nie tylko w sposób formalny, ale też poza- i nieformalny.

Obecnie w Polsce kwalifikacje są nadawane zarówno w systemach oświaty i szkolnictwa wyższego, jak i poza nimi przez różne instytucje i organizacje. Należy podkreślić, że w systemach oświaty i szkolnictwa wyższego od wielu lat obowiązują określone (wynikające z przepisów prawa, choć okresowo nawet istotnie zmieniane) zasady nadawania kwalifikacji i zapewniania określającej jakość kwalifikacji jakości kształcenia ${ }^{8}$. Z kolei kwalifikacje nadawane poza systemami oświaty i szkolnictwa wyższego są regulowane przez różne przepisy lub inne regulacje ustanowione przez różne podmioty, takie jak związki i organizacje zawodowe, instytucje szkoleniowe, korporacje. Zdobywanie w Polsce kwalifikacji po ukończeniu edukacji szkolnej i akademickiej jest często normalną drogą rozwoju zawodowego, co wiąże się też z uzyskiwaniem określonych uprawnień zawodowych. Przykładem są specjalizacje:

- lekarskie i pielęgniarskie;

- w zakresie zawodów prawniczych: radca prawny, adwokat, prokurator, sędzia;

- służb finansowych: biegły rewident, makler giełdowy, doradca podatkowy;

- zawodowego szkolnictwa wojskowego;

- branżowe i zawodowe, co dotyczy branży budowlanej, elektrycznej i energetycznej, rzemiosła, obsługi maszyn i urządzeń, komunikacji lądowej, lotnictwa, żeglugi i in.

Analizując funkcjonujący w Polsce system kwalifikacji, można zatem stwierdzić (ryc. 1), że cechuje go stosunkowo duża różnorodność, a jednocześnie autonomia zarówno podmiotów przyznających kwalifikacje, jak i zasad uzyskiwania kompetencji i przyznawania kwalifikacji. Poza kwalifikacjami uzyskiwanymi w ramach edukacji formalnej kwalifikacje rzadko można odnosić do siebie, a ponadto przy ich przyznawaniu zwykle nie są uwzględniane kwalifikacje nabyte wcześniej. Kwalifikowanie kompetencji zdobywanych poza zorganizowanymi formami edukacji jest też rozproszone, a dostęp do informacji nie zawsze jest pełny. Wskazany sposób funkcjonowania w Polsce „rynku kwalifikacji” wpływa na kształtowanie się postawy - zarówno wśród ludzi, jak i pracodawców oraz podmiotów szkoleniowych - uczenia się przez całe życie (Raport referencyjny... 2013). Poza dążeniem do upowszechnienia i ujednolicenia rozwiązań stosowanych w Polsce i w innych krajach Europy, w których efekty uczenia się są głównym punktem odniesienia, podstawę budowy systemów kwalifikacji stanowią też założenia, takie jak:

1) umożliwienie walidowania efektów uczenia uzyskanych niezależnie od formy uczenia się,

2) rozwijanie możliwości akumulowania i przenoszenia osiągnięć,

3) powszechne wdrażanie procedur zapewniania jakości kwalifikacji, zgodnie ze standardami przyjętymi w Europie.

Omówione problemy stały się podstawą budowy w Polsce opartego na efektach uczenia krajowego systemu kwalifikacji. Część działań w tym zakresie została już wprowadzona9 Kolejny etap to modyfikacja rozwiązań systemowych, czyli wdrożenie narzędzi integrujących system kwalifikacji.

\footnotetext{
${ }^{8}$ Zasady te określają głównie prawo oświatowe, prawo o szkolnictwie wyższym, przepisy dotyczące oceny jakości kształcenia i jej oceny.

${ }^{9}$ W Polsce od wielu lat jest realizowana reforma szkolnictwa wprowadzająca efekty uczenia się przez całe życie jako punkt odniesienia dla polityki edukacyjnej. W latach 2008-2011 przeprowadzono reformy szkolnictwa ogólnokształcącego i zawodowego. W szkolnictwie wyższym kluczowe zmiany w tym zakresie wprowadzono w 2011 r., wdrażając krajowe ramy kwalifikacji dla szkolnictwa wyższego.
} 


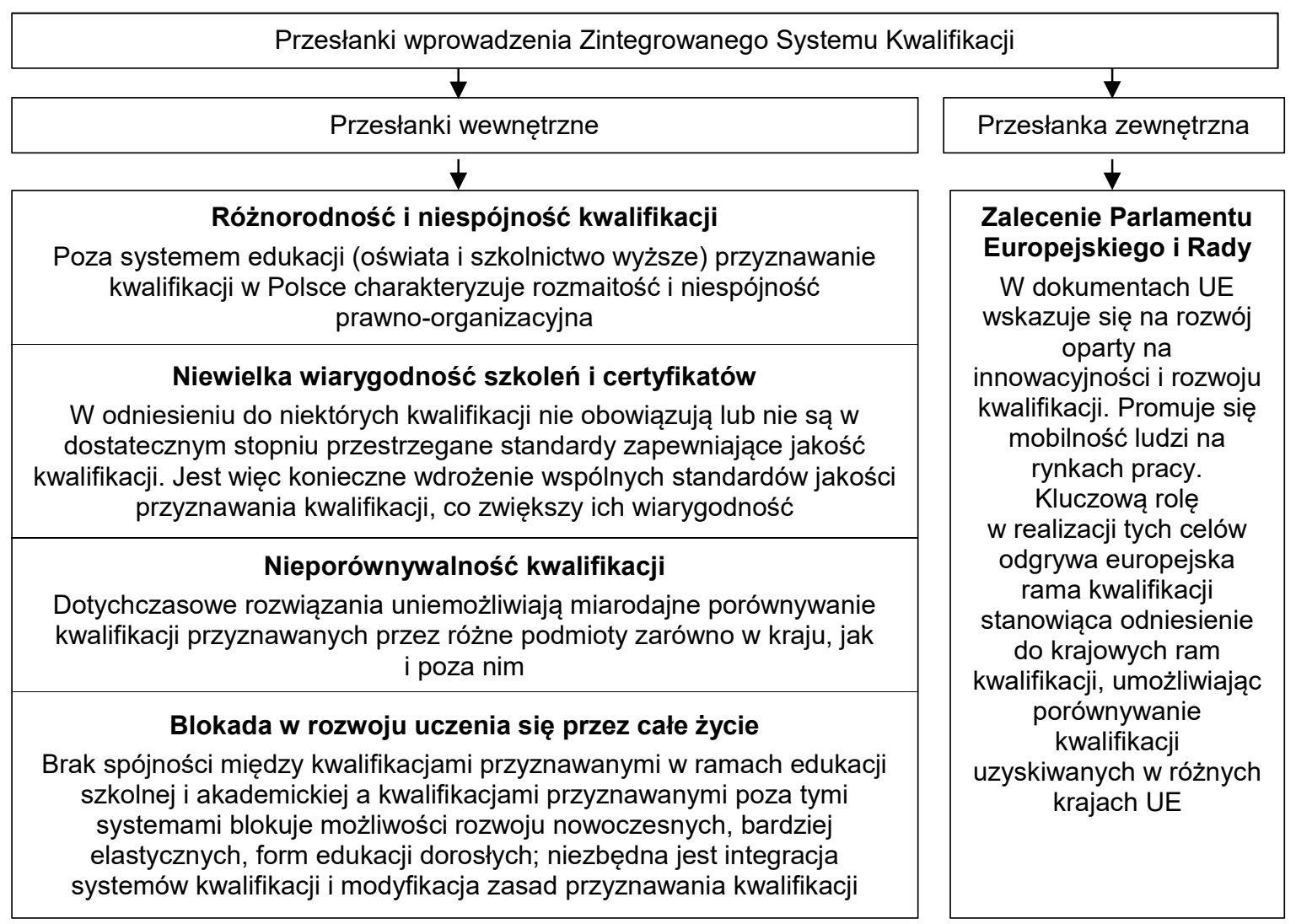

Ryc. 1. Przesłanki wprowadzenia w Polsce ZSK

Źródło: opracowano na podstawie: Zintegrowany System Kwalifikacji w Polsce (https://www.kwalifikacje.gov.pl/ /download/prezentacja_zsk.pdf).

\section{INSTRUMENTY ZINTEGROWANEGO SYSTEMU KWALIFIKACJI}

Przez krajowy system kwalifikacji rozumieć należy ogół działań związanych z potwierdzaniem efektów uczenia się na potrzeby rynku pracy, społeczeństwa obywatelskiego oraz indywidualnego rozwoju osób uczących się (Raport referencyjny... 2013). System ten obejmuje w szczególności tworzenie, nadawanie (przyznawanie) i uznawanie kwalifikacji, a także zapewnianie ich jakości. W Polsce jego funkcję od 2016 r. pełni Zintegrowany System Kwalifikacji (ZSK). Jest to ustanowiony przepisami prawa (Ustawa z dnia 22 grudnia 2015 r. o Zintegrowanym Systemie Kwalifikacji) zbiór zasad, standardów, funkcji i procedur regulujących procesy: nadawania kwalifikacji, ich opisu, rejestracji kwalifikacji, zapewniania jakości walidacji i certyfikowania kwalifikacji oraz sprawowania nadzoru nad tymi procesami. ZSK zapewniać ma:

1) jakość nadawanych kwalifikacji,

2) możliwość uznawania efektów uczenia się uzyskanych w systemach edukacji pozaformalnej i poprzez uczenie się nieformalne,

3) możliwość etapowego gromadzenia osiągnięć oraz uznawania osiągnięć,

4) dostęp do informacji o kwalifikacjach możliwych do uzyskania na terytorium Rzeczypospolitej Polskiej, 
5) możliwość porównania kwalifikacji uzyskanych na terytorium Rzeczypospolitej Polskiej z kwalifikacjami uzyskanymi w innych państwach członkowskich Unii Europejskiej. Utworzenie w Polsce ZSK wymaga wdrożenia dwóch instrumentów, to jest (ryc. 2):

- polskiej ramy kwalifikacji (PRK),

- zintegrowanego rejestru kwalifikacji (ZRK).

Schemat rozwiązania systemowego w ZSK jest następujący (por. ryc. 2):

- wszystkie kwalifikacje włączone do ZSK są wpisane do zintegrowanego rejestru kwalifikacji (ZRK);

- każda kwalifikacja włączona do ZSK musi być opisana w określony sposób i mieć przypisany poziom PRK;

- poziom PRK wynika z porównania wymagań dotyczących kwalifikacji z charakterystykami poziomów w PRK;

- kwalifikację włączoną do ZSK można nadać wyłącznie na podstawie pozytywnego wyniku walidacji (sprawdzenia, czy wymagane efekty uczenia się są osiągnięte);

- kwalifikacje włączone do ZSK mogą nadawać wyłącznie instytucje uprawnione przez właściwego ministra lub przepisy prawa;

- każda instytucja nadająca kwalifikacje włączone do ZSK (instytucja certyfikująca) jest objęta wewnętrznym i zewnętrznym systemem zapewniania jakości; zasady zapewniania jakości określa ustawa o ZSK;

- funkcję podmiotu zewnętrznego zapewniania jakości powierza minister właściwy dla danej kwalifikacji; ministrowie właściwi sprawują nadzór nad jakością nadawania kwalifikacji należących do ich działów administracji rządowej;

- funkcjonowanie ZSK jest koordynowane przez Ministra Edukacji Narodowej.

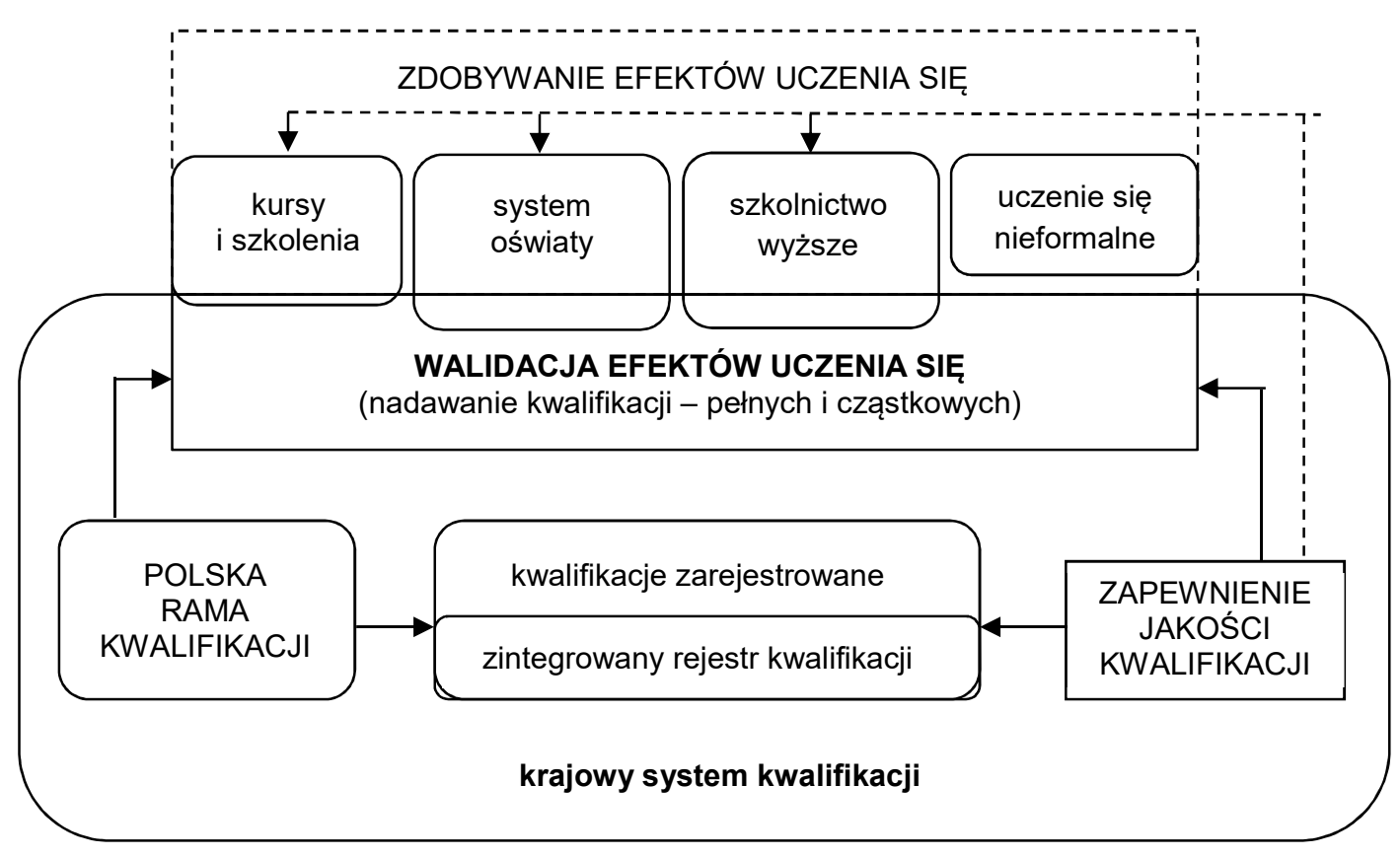

Ryc. 2. Schemat krajowego systemu kwalifikacji w Polsce Źródło: Sławiński i in. (2013). 
Wprowadzenie ZSK ma zapewnić porównywalność dyplomów, świadectw i certyfikatów zarówno w Polsce, jak i za granicą. Ma też wpłynąć na poprawę jakości kursów i szkoleń. Wśród korzyści z wprowadzenia ZSK wymienia się (Zintegrowany Rejestr Kwalifikacji, https://www.parp.gov.pl):

- szybszy, prostszy i bardziej dostępny sposób uzyskania zaświadczenia czy certyfikatu o zdobytych kwalifikacjach;

- czytelny sposób oceny oferty instytucji edukacyjnych czy firm szkoleniowych;

- prostsze planowanie rozwoju zawodowego;

- łatwiejszą i czytelniejszą metodę udowadniania kwalifikacji;

- zwiększenie przejrzystości i usystematyzowanie oferty instytucji szkoleniowych zajmujących się różnymi formami kształcenia.

Głównym elementem przedstawionego systemu kwalifikacji jest polska rama kwalifikacji. W jej strukturze, podobnie jak w europejskiej ramie kwalifikacji, wyróżnia się 8 poziomów kwalifikacji ${ }^{10}$. Każdy z nich jest opisany za pomocą ogólnych charakterystyk efektów uczenia się. Unikatowym rozwiązaniem zastosowanym w Polsce jest wprowadzenie dwustopniowych charakterystyk poziomów PRK, o różnym stopniu szczegółowości. Stanowią je charakterystyki (Ustawa z dnia 22 grudnia 2015 r. o Zintegrowanym Systemie Kwalifikacji, art. 5 ust. 2):

1) uniwersalne poziomów 1-8 pierwszego stopnia,

2) drugiego stopnia, stanowiące rozwinięcie uniwersalnych charakterystyk pierwszego stopnia, które obejmują:

a) charakterystyki poziomów 1-4 drugiego stopnia typowe dla kwalifikacji o charakterze ogólnym, uzyskiwanych w ramach edukacji formalnej, edukacji pozaformalnej oraz uczenia się nieformalnego;

b) charakterystykę poziomu 5 drugiego stopnia typową dla kwalifikacji uzyskiwanych po uzyskaniu kwalifikacji pełnej na poziomie 4;

c) charakterystyki poziomów 6-8 drugiego stopnia typowe dla kwalifikacji uzyskiwanych w ramach szkolnictwa wyższego po uzyskaniu kwalifikacji pełnej na poziomie 4;

d) charakterystyki poziomów 1-8 drugiego stopnia typowe dla kwalifikacji o charakterze zawodowym, uzyskiwanych w ramach edukacji formalnej, edukacji pozaformalnej oraz nieformalnego uczenia się.

Uniwersalne charakterystyki poziomów oraz charakterystyki drugiego stopnia należy czytać łącznie.

Opis poszczególnych poziomów kwalifikacji jest ujęty w kategoriach wiedzy, umiejętności i kompetencji społecznych ${ }^{11}$. Poziom PRK określa zakres i stopień złożoności wymaganych efektów uczenia się właściwych dla kwalifikacji danego poziomu, sformułowanych za pomocą charakterystyk efektów uczenia się ${ }^{12}$. Charakterystyki kolejnych poziomów PRK odzwierciedlają zatem postępy osiągane przez osobę uczącą się, wskazując, jak w wyniku uczenia się następuje przyrost:

- wiedzy (jej głębi i zakresu);

\footnotetext{
10 Przepisy rozróżniają tzw. kwalifikacje pełne i cząstkowe, co omówiono w dalszej części artykułu.

11 Por. art. 2, pkt 16 Ustawy z dnia 22 grudnia 2015 r. o Zintegrowanym Systemie Kwalifikacji. Punktem odniesienia dla charakterystyk poziomów PRK są odpowiednie zapisy w europejskiej ramie kwalifikacji (ERK), przez co jest możliwe przejrzyste ukazanie zaproponowanych odniesień polskich poziomów kwalifikacji do odpowiadających im poziomów w ERK.

12 Por. art. 2, pkt 17 Ustawy z dnia 22 grudnia 2015 r. o Zintegrowanym Systemie Kwalifikacji.
} 
- umiejętności (rozwiązywania problemów, stosowania wiedzy w praktyce, organizacyjne, uczenia się i komunikowania);

- kompetencji społecznych (gotowości do współpracy i do podjęcia odpowiedzialności za realizację powierzonych zadań).

Warto powtórzyć, że dla określania poziomu PRK nie ma znaczenia, czy wymagane dla kwalifikacji efekty uczenia się są osiągane w ramach edukacji zorganizowanej czy w inny sposób.

Do szkolnictwa wyższego odnoszą się w szczególności poziomy 6-8 PRK. Charakterystyki poziomów 6 i 7 określają wymagania dotyczące efektów uczenia się umożliwiające nadanie kwalifikacji pełnych po ukończeniu studiów odpowiednio pierwszego i drugiego stopnia oraz po studiach kończących się uzyskaniem kompetencji inżynierskich. W ramach poziomu 8 PRK opisane zostały efekty uczenia się uzyskane w wyniku ukończenia studiów doktoranckich. Z kolei kwalifikacjom cząstkowym nadawanym przez uczelnie po ukończeniu studiów podyplomowych przypisuje się poziom 6 lub 7.

W odniesieniu do szkolnictwa wyższego podstawy budowy PRK tworzą dwa akty prawne:

- Ustawa z dnia 22 grudnia 2015 r. o Zintegrowanym Systemie Kwalifikacji. DzU z 2016 r., poz. 64 ze zm.,

- Rozporządzenie Ministra Nauki i Szkolnictwa Wyższego z dnia 26 września 2016 r. w sprawie charakterystyk drugiego stopnia Polskiej Ramy Kwalifikacji typowych dla kwalifikacji uzyskiwanych w ramach szkolnictwa wyższego po uzyskaniu kwalifikacji pełnej na poziomie 4 - poziomy 6-8. DzU z 2016 r., poz. 1594.

W Ustawie zostały zawarte uniwersalne charakterystyki poziomów 6-8 PRK, które należy odnosić do określonej dziedziny uczenia się (tab. 1), a także elementy opisu charakterystykach typowych dla kwalifikacji uzyskiwanych w ramach szkolnictwa wyższego (tab. 2).

Minister Nauki i Szkolnictwa Wyższego w drodze rozporządzenia sformułował natomiast charakterystyki dla drugiego stopnia kwalifikacji, które obejmują:

- w części I: charakterystyki drugiego stopnia PRK dla poziomów 6-8 - tzw. charakterystyki typowe dla kwalifikacji uzyskiwanych w ramach szkolnictwa wyższego;

- w części II: charakterystyki drugiego stopnia dla poszczególnych obszarów kształcenia w ramach szkolnictwa wyższego dla poziomów 6 i 7 (rozwinięcie opisów zawartych w części I).

Przykład charakterystyk typowych dla poziomu 6 PRK, z podziałem na efekty uczenia się w zakresie wiedzy, umiejętności i kompetencji społecznych, przedstawia tab. 3, natomiast charakterystyki drugiego stopnia dla poziomu 6 PRK, dotyczące obszaru nauk społecznych, profilu ogólnoakademickiego przedstawia tab. 4.

Przedstawione w tab. 2-4 charakterystyki pozwalają stwierdzić, że osoba posiadająca kwalifikacje 6 poziomu PRK jest przygotowana do wykorzystania posiadanej wiedzy do formułowania i rozwiązywania złożonych, nietypowych problemów oraz do wykonywania zadań w nie w pełni przewidywalnych warunkach, a także do planowania i organizowania pracy zespołu lub małej organizacji realizujących takie zadania. 
Tabela 1. Uniwersalne charakterystyki poziomów 6-8

\begin{tabular}{|c|c|c|c|c|c|c|}
\hline \multirow[t]{2}{*}{ Poziom } & \multicolumn{2}{|c|}{$\begin{array}{l}\text { Wiedza: absolwent zna } \\
\text { i rozumie }\end{array}$} & \multicolumn{2}{|c|}{ Umiejętności: absolwent potrafi } & \multicolumn{2}{|c|}{$\begin{array}{l}\text { Kompetencje społeczne: } \\
\text { absolwent jest gotowy }\end{array}$} \\
\hline & kod & opis & kod & opis & kod & opis \\
\hline 6 & P6W_U & $\begin{array}{l}\text { w zaawansowanym } \\
\text { stopniu fakty, teorie, } \\
\text { metody oraz złożone } \\
\text { zależności między nimi, } \\
\text { różnorodne, złożone } \\
\text { uwarunkowania pro- } \\
\text { wadzonej działalności }\end{array}$ & P6U_U & $\begin{array}{l}\text { innowacyjnie wykonywać za- } \\
\text { dania oraz rozwiązywać } \\
\text { złożone i nietypowe pro- } \\
\text { blemy w zmiennych i nie } \\
\text { w pełni przewidywalnych } \\
\text { warunkach samodzielnie } \\
\text { planować własne uczenie } \\
\text { się przez całe życie komu- } \\
\text { nikować się z otoczeniem, } \\
\text { uzasadniać swoje stano- } \\
\text { wisko }\end{array}$ & P6U_K & $\begin{array}{l}\text { do kultywowania i upow- } \\
\text { szechniania wzorów właś- } \\
\text { ciwego postępowania } \\
\text { wśrodowisku pracy i poza } \\
\text { nim, do samodzielnego } \\
\text { podejmowania decyzji, } \\
\text { krytycznej oceny działań } \\
\text { własnych, działań zespo- } \\
\text { łów, którymi kieruje, i or- } \\
\text { ganizacji, w których uczes- } \\
\text { tniczy, do przyjmowania } \\
\text { odpowiedzialności za } \\
\text { skutki tych działań }\end{array}$ \\
\hline 7 & P7W_U & $\begin{array}{l}\text { w pogłębiony sposób } \\
\text { wybrane fakty, teorie, } \\
\text { metody oraz złożone } \\
\text { zależności między ni- } \\
\text { mi, także w powią- } \\
\text { zaniu z innymi dzie- } \\
\text { dzinami różnorodne, } \\
\text { złożone uwarunko- } \\
\text { wania i aksjologiczny } \\
\text { kontekst prowadzo- } \\
\text { nej działalności }\end{array}$ & P7U_U & $\begin{array}{l}\text { wykonywać zadania oraz } \\
\text { formułować i rozwiązywać } \\
\text { problemy, z wykorzysta- } \\
\text { niem nowej wiedzy, także } \\
\text { z innych dziedzin samo- } \\
\text { dzielnie planować własne } \\
\text { uczenie się przez całe } \\
\text { życie i ukierunkowywać } \\
\text { innych w tym zakresie } \\
\text { komunikować się z różno- } \\
\text { rodnymi kręgami odbior- } \\
\text { ców, odpowiednio uzasad- } \\
\text { niać stanowiska }\end{array}$ & P7U_K & $\begin{array}{l}\text { do tworzenia i rozwija- } \\
\text { nia wzorów właściwego } \\
\text { postępowania w środo- } \\
\text { wisku pracy i życia, do } \\
\text { podejmowania inicjatyw, } \\
\text { krytycznej oceny siebie } \\
\text { oraz zespołów i organi- } \\
\text { zacji, w których uczest- } \\
\text { niczy, do przewodzenia } \\
\text { grupie i ponoszenia od- } \\
\text { powiedzialności za nią }\end{array}$ \\
\hline 8 & P8W_U & $\begin{array}{l}\text { światowy dorobek na- } \\
\text { ukowy i twórczy oraz } \\
\text { wynikające z niego } \\
\text { implikacje dla praktyki }\end{array}$ & P8U_U & $\begin{array}{l}\text { dokonywać analizy i twór- } \\
\text { czej syntezy dorobku na- } \\
\text { ukowego i twórczego w ce- } \\
\text { lu identyfikowania i roz- } \\
\text { wiązywania problemów ba- } \\
\text { dawczych oraz związa- } \\
\text { nych z działalnością inno- } \\
\text { wacyjną i twórczą; two- } \\
\text { rzyć nowe elementy tego } \\
\text { dorobku, samodzielnie pla- } \\
\text { nować własny rozwój oraz } \\
\text { inspirować rozwój innych } \\
\text { osób, uczestniczyć w wy- } \\
\text { mianie doświadczeń i idei, } \\
\text { także w środowisku mię- } \\
\text { dzynarodowym }\end{array}$ & P8U_K & $\begin{array}{l}\text { do niezależnego bada- } \\
\text { nia powiększającego ist- } \\
\text { niejący dorobek nauko- } \\
\text { wy i twórczy, do podej- } \\
\text { mowania wyzwań w sfe- } \\
\text { rze zawodowej i publi- } \\
\text { cznej, z uwzględnieniem: } \\
\text { ich etycznego wymiaru, } \\
\text { odpowiedzialności za ich } \\
\text { skutki oraz kształtowa- } \\
\text { nia wzorów właściwego } \\
\text { postępowania w takich } \\
\text { sytuacjach }\end{array}$ \\
\hline
\end{tabular}

Źródło: opracowano na podstawie: Załącznik do Ustawy z dnia 22 grudnia 2015 r. o Zintegrowanym Systemie Kwalifikacji.

Tabela 2. Kategorie opisowe i aspekty o podstawowym znaczeniu dla kompletnego opisu efektów uczenia się, dotyczące charakterystyk poziomów typowych dla kwalifikacji uzyskiwanych w ramach szkolnictwa wyższego

\begin{tabular}{|l|l|l|}
\hline \multicolumn{2}{|c|}{ Kategorie opisowe } & \multicolumn{1}{c|}{ Aspekty o podstawowym znaczeniu } \\
\hline \multirow{4}{*}{ Wiedza } & zakres i głębia & kompletność perspektywy poznawczej i zależności \\
\cline { 2 - 3 } & kontekst & uwarunkowania, skutki \\
\hline \multirow{4}{*}{ Umiejętności } & wykorzystanie wiedzy & rozwiązywanie problemów i wykonywanie zadań \\
\cline { 2 - 3 } & komunikowanie się & $\begin{array}{l}\text { odbieranie i tworzenie wypowiedzi, upowszechnianie wiedzy } \\
\text { w środowisku naukowym, posługiwanie się językiem obcym }\end{array}$ \\
\cline { 2 - 3 } & organizacja pracy & planowanie, praca zespołowa \\
\cline { 2 - 3 } & uczenie się & planowanie własnego rozwoju i rozwoju innych osób \\
\hline \multirow{4}{*}{ Kompetencje } & oceny & krytyczne podejście \\
\cline { 2 - 3 } & odpowiedzialność & $\begin{array}{l}\text { wypełnianie zobowiązań społecznych, działanie na rzecz interesu } \\
\text { publicznego }\end{array}$ \\
\cline { 2 - 3 } & rola zawodowa & niezależność i rozwój etosu zawodu \\
\hline
\end{tabular}

Źródło: Polska rama... (2016). 
Tabela 3. Typowe charakterystyki kwalifikacji uzyskiwanych w ramach szkolnictwa wyższego poziom 6 PRK

\begin{tabular}{|c|c|c|c|}
\hline $\begin{array}{l}\text { Kategorie } \\
\text { charakterystyki } \\
\text { kwalifikacji }\end{array}$ & $\begin{array}{l}\text { Kategorie opisowe / } \\
\text { aspekty o podstawowym } \\
\text { znaczeniu }\end{array}$ & $\begin{array}{l}\text { Kod } \\
\text { składnika } \\
\text { opisu }\end{array}$ & Poziom 6 \\
\hline \multirow[t]{3}{*}{$\begin{array}{l}\text { Wiedza: } \\
\text { absolwent zna } \\
\text { i rozumie }\end{array}$} & $\begin{array}{l}\text { zakres i głębia / komplet- } \\
\text { ność perspektywy poznaw- } \\
\text { czej i zależności }\end{array}$ & P6S_WG & $\begin{array}{l}\text { w zaawansowanym stopniu - wybrane fakty, } \\
\text { obiekty i zjawiska oraz dotyczące ich metody } \\
\text { i teorie wyjaśniające złożone zależności między } \\
\text { nimi, stanowiące podstawową wiedzę ogólną } \\
\text { z zakresu dyscyplin naukowych lub artystycznych } \\
\text { tworzących podstawy teoretyczne oraz wybrane } \\
\text { zagadnienia z zakresu wiedzy szczegółowej - } \\
\text { właściwe dla programu kształcenia }\end{array}$ \\
\hline & \multirow[t]{2}{*}{$\begin{array}{l}\text { kontekst / uwarunkowania, } \\
\text { skutki }\end{array}$} & \multirow[t]{2}{*}{ P6S_WK } & $\begin{array}{l}\text { fundamentalne dylematy współczesnej cywili- } \\
\text { zacji }\end{array}$ \\
\hline & & & $\begin{array}{l}\text { podstawowe ekonomiczne, prawne i inne uwa- } \\
\text { runkowania różnych rodzajów działań zwią- } \\
\text { zanych z nadaną kwalifikacją, w tym pod- } \\
\text { stawowe pojęcia i zasady z zakresu ochrony } \\
\text { własności przemysłowej i prawa autorskiego }\end{array}$ \\
\hline \multirow[t]{6}{*}{$\begin{array}{l}\text { Umiejętności: } \\
\text { absolwent potrafi }\end{array}$} & $\begin{array}{l}\text { wykorzystanie wiedzy / roz- } \\
\text { wiązywane problemy i wy- } \\
\text { konywane zadania }\end{array}$ & P6S_UW & $\begin{array}{l}\text { wykorzystywanie posiadanej wiedzy - formu- } \\
\text { łowanie i rozwiązywanie złożonych i nietypo- } \\
\text { wych problemów oraz wykonywanie zadania } \\
\text { w warunkach nie w pełni przewidywalnych przez: } \\
\text { - właściwy dobór źródeł oraz informacji z nich } \\
\text { pochodzących, dokonywanie oceny, kryty- } \\
\text { cznej analizy i syntezy tych informacji, } \\
\text { - dobór oraz stosowanie właściwych metod } \\
\text { i narzędzi, w tym zaawansowanych technik } \\
\text { informacyjno-komunikacyjnych (ICT) }\end{array}$ \\
\hline & \multirow{3}{*}{$\begin{array}{l}\text { komunikowanie się / od- } \\
\text { bieranie i tworzenie wypo- } \\
\text { wiedzi, upowszechnianie wie- } \\
\text { dzy w środowisku nauko- } \\
\text { wym i posługiwanie się ję- } \\
\text { zykiem obcym }\end{array}$} & \multirow[t]{3}{*}{ P6S_UK } & $\begin{array}{l}\text { komunikowanie się z użyciem specjalistycznej } \\
\text { terminologii }\end{array}$ \\
\hline & & & $\begin{array}{l}\text { branie udziału w debacie, przedstawianie i oce- } \\
\text { nianie różnych opinii i stanowisk oraz dys- } \\
\text { kutowanie o nich }\end{array}$ \\
\hline & & & $\begin{array}{l}\text { posługiwanie się językiem obcym na poziomie } \\
\text { B2 europejskiego systemu opisu kształcenia } \\
\text { językowego }\end{array}$ \\
\hline & $\begin{array}{l}\text { organizacja pracy / plano- } \\
\text { wanie i praca zespołowa }\end{array}$ & P6S_UO & $\begin{array}{l}\text { planowanie i organizowanie pracy - indywi- } \\
\text { dualnej oraz w zespole }\end{array}$ \\
\hline & $\begin{array}{l}\text { uczenie się / planowanie } \\
\text { własnego rozwoju i rozwoju } \\
\text { innych osób }\end{array}$ & P6S_UU & $\begin{array}{l}\text { samodzielne planowanie i realizowanie włas- } \\
\text { nego uczenia się przez całe życie }\end{array}$ \\
\hline \multirow{6}{*}{$\begin{array}{l}\text { Kompetencje } \\
\text { społeczne: } \\
\text { absolwent jest } \\
\text { gotów do }\end{array}$} & \multirow[t]{2}{*}{ oceny / krytyczne podejście } & \multirow[t]{2}{*}{ P6S_KK } & krytyczna ocena posiadanej wiedzy \\
\hline & & & $\begin{array}{l}\text { uznawanie znaczenia wiedzy w rozwiązywaniu } \\
\text { problemów poznawczych i praktycznych }\end{array}$ \\
\hline & \multirow{3}{*}{$\begin{array}{l}\text { odpowiedzialność / wypeł- } \\
\text { nianie zobowiązań społecz- } \\
\text { nych i działanie na rzecz } \\
\text { interesu publicznego }\end{array}$} & \multirow[t]{3}{*}{ P6S_KO } & $\begin{array}{l}\text { wypełnianie zobowiązań społecznych, współ- } \\
\text { organizowanie działalności na rzecz środowiska } \\
\text { społecznego }\end{array}$ \\
\hline & & & $\begin{array}{l}\text { inicjowanie działania na rzecz interesu publi- } \\
\text { cznego }\end{array}$ \\
\hline & & & myślenie i działanie w sposób przedsiębiorczy \\
\hline & $\begin{array}{l}\text { rola zawodowa / niezależ- } \\
\text { ność i rozwój etosu }\end{array}$ & P6S_KR & $\begin{array}{l}\text { odpowiedzialne pełnienie ról zawodowych, w tym: } \\
\text { - przestrzeganie zasad etyki zawodowej i wy- } \\
\text { maganie tego od innych } \\
\text { - dbałość o dorobek i tradycje zawodu }\end{array}$ \\
\hline
\end{tabular}

Źródło: opracowano na podstawie: Załącznik do Rozporządzenia Ministra Nauki i Szkolnictwa Wyższego z dnia 26 września 2016 r. w sprawie charakterystyk drugiego stopnia... 
Tabela 4. Charakterystyki drugiego stopnia PRK dla obszaru kształcenia w zakresie nauk społecznych dla profilu ogólnoakademickiego - poziom 6

\begin{tabular}{|c|c|}
\hline Kod składnika opisu & Profil ogólnoakademcki - poziom 6 \\
\hline \multicolumn{2}{|r|}{ Wiedza: absolwent zna i rozumie } \\
\hline P6S_WG & $\begin{array}{l}\text { teorie oraz ogólna metodologia badań w zakresie dyscyplin naukowych właściwych } \\
\text { dla kierunku studiów }\end{array}$ \\
\hline P6S_WG & $\begin{array}{l}\text { charakter, miejsce i znaczenie nauk społecznych w systemie nauk oraz ich relacje } \\
\text { do innych nauk }\end{array}$ \\
\hline P6S_WG & $\begin{array}{l}\text { cechy człowieka jako twórcy kultury i podmiotu konstytuującego struktury społeczne } \\
\text { oraz zasady ich funkcjonowania }\end{array}$ \\
\hline P6S_WK & $\begin{array}{l}\text { zasady ochrony własności przemysłowej i prawa autorskiego oraz formy rozwoju } \\
\text { indywidualnej przedsiębiorczości }\end{array}$ \\
\hline \multicolumn{2}{|r|}{ Umiejętności: absolwent potrafi } \\
\hline P6S_UW & $\begin{array}{l}\text { identyfikowanie i interpretowanie podstawowych zjawisk i procesów społecznych } \\
\text { z wykorzystaniem wiedzy z dyscyplin naukowych właściwych dla kierunku studiów }\end{array}$ \\
\hline P6S_UW & $\begin{array}{l}\text { analizowanie i prognozowanie procesów i zjawisk społecznych z wykorzystaniem } \\
\text { standardowych metod i narzędzi dyscyplin naukowych właściwych dla kierunku } \\
\text { studiów }\end{array}$ \\
\hline P6S_UW & $\begin{array}{l}\text { prawidłowe posługiwanie się systemami normatywnymi w celu rozwiązania zadania } \\
\text { z zakresu dziedzin nauki i dyscyplin naukowych właściwych dla kierunku studiów }\end{array}$ \\
\hline
\end{tabular}

Źródło: opracowano na podstawie: Załącznik do rozporządzenia Ministra Nauki i Szkolnictwa Wyższego z dnia 26 września 2016 r. w sprawie charakterystyk drugiego stopnia...

Opis ten wskazuje, że absolwent studiów pierwszego stopnia lub osoba, która uzyskała kwalifikacje na tym poziomie:

1) zna w zaawansowanym stopniu wybrane fakty, obiekty i zjawiska oraz dotyczące ich metody i teorie wyjaśniające złożone zależności między nimi, stanowiące podstawową wiedzę ogólną z danego zakresu, jak również fundamentalne dylematy współczesnej cywilizacji oraz podstawowe ekonomiczne, prawne i inne uwarunkowania różnych rodzajów działań związanych z nadaną kwalifikacją, w tym podstawowe pojęcia i zasady z zakresu ochrony własności przemysłowej i prawa autorskiego;

2) potrafi:

- dokonać oceny, krytycznej analizy i syntezy informacji pochodzących z właściwie dobranych źródeł;

- właściwie dobrać oraz zastosować dostępne metody, narzędzia i technologie służące realizacji podejmowanych zadań, a także dokonać ich prostej adaptacji;

- uwzględnić w prowadzonej działalności różnorodne złożone uwarunkowania (ekonomiczne, prawne, społeczne i inne) oraz dokonać analizy i oceny prowadzonej działalności w kontekście tych uwarunkowań;

- wykorzystać umiejętność komunikowania się z użyciem specjalistycznej terminologii, przedstawiania, oceniania oraz dyskutowania różnych opinii i stanowisk w celu utrzymywania właściwych relacji w związku z prowadzoną działalnością;

- samodzielnie planować własne uczenie się przez całe życie;

3) jest gotowa:

- odpowiedzialnie pełnić funkcje zawodowe, w prowadzonej działalności kultywować i upowszechniać wzory właściwego postępowania, uczestniczyć w promowaniu kultury projakościowej, kultury współpracy i zasad etyki zawodowej;

- inicjować działania na rzecz interesu publicznego. 
Polska rama kwalifikacji jest narzędziem niezbędnym do klasyfikowania kwalifikacji włączonych do ZSK, a jednocześnie umożliwia funkcjonowanie drugiego z narzędzi tego systemu, to jest zintegrowanego rejestru kwalifikacji (ZRK). Jest to publiczny rejestr, w którym są umieszczone informacje o kwalifikacjach nadawanych w Polsce. Oprócz informacji o kwalifikacjach w ZRK są gromadzone informacje o instytucjach odpowiedzialnych za potwierdzanie zdobytych kwalifikacji - niezależnie od tego, czy zostały one wcześniej ujęte w innych rejestrach prowadzonych na potrzeby resortów, branż, środowisk lub instytucji.

Na potrzeby ZRK zdefiniowano pojęcie kwalifikacji jako zestaw efektów uczenia się (wiedzy, umiejętności, kompetencji społecznych) zgodnych $\mathrm{z}$ ustalonymi wymaganiami, których osiągnięcie zostało sprawdzone oraz formalnie potwierdzone (przez wydanie dyplomu, świadectwa, certyfikatu). W przepisach rozróżniono kwalifikacje:

1) pełne - nadawane wyłącznie w ramach systemów oświaty i szkolnictwa wyższego, np. potwierdzone przez świadectwo maturalne;

2) cząstkowe nadawane również przez inne instytucje szkoleniowe, np. prawo jazdy.

Do klasyfikowania kwalifikacji włączonych do ZSK służy polska rama kwalifikacji, która umożliwia porównywanie kwalifikacji z różnych dziedzin w kraju i w wymiarze międzynarodowym. Poziomy kwalifikacji są umieszczane na dokumentach potwierdzających nadanie kalifikacji za pomocą oznaczenia odpowiedniego poziomu PRK (zob. Rozporządzenie Ministra Edukacji Narodowej z dnia 13 lipca 2016 r.).

Zintegrowany rejestr kwalifikacji (ZRK) prowadzi Polska Agencja Rozwoju Przedsiębiorczości $\mathrm{w}$ formie portalu internetowego dostępnego na stronie https://rejestr.kwalifikacje.gov.pl/. Każdy użytkownik ZRK ma możliwość:

1) przeglądania / wyszukiwania kwalifikacji;

2) przeglądania / wyszukiwania instytucji systemu kwalifikacji;

3) dostępu do upublicznionych dokumentów (np. do instrukcji, wzorów wniosków), komunikatów, informacji na temat złożonych wniosków i in.

Zbiór danych dotyczących każdej kwalifikacji udostępniany za pomocą portalu ZRK docelowo ma obejmować:

1) informacje ogólne o kwalifikacji, takie jak:

- oficjalna nazwa kwalifikacji,

- rodzaj kwalifikacji i poziom w PRK, który jest do niej przypisany,

- rodzaj dokumentu poświadczającego kwalifikację,

- krótka charakterystyka kwalifikacji,

- orientacyjny koszt uzyskania dokumentu potwierdzającego otrzymanie danej kwalifikacji,

- orientacyjny nakład pracy potrzebny do uzyskania kwalifikacji,

- kwalifikacje stanowiące podbudowę danej kwalifikacji (wymagane kwalifikacje wstępne),

- dodatkowe warunki, jakie musi spełniać osoba przystępująca do walidacji,

- odniesienie do kwalifikacji o zbliżonym charakterze oraz wskazanie kwalifikacji ujętych w ZRK zawierających wspólne zestawy efektów uczenia się,

- typowe możliwości wykorzystania kwalifikacji,

- propozycja odniesienia do poziomu sektorowych ram kwalifikacji;

2) efekty uczenia się, które trzeba osiągnąć, aby uzyskać określoną kwalifikację (wymagane kompetencje); 
3) informacje o instytucjach uprawnionych do nadawania kwalifikacji i prowadzących ewaluację zewnętrzną;

4) pozostałe informacje związane z kwalifikacją, takie jak: okres ważności dokumentu potwierdzającego nadanie kwalifikacji i warunki przedłużenia jego ważności, nazwa dokumentu potwierdzającego nadanie kwalifikacji, uprawnienia związane z posiadaniem kwalifikacji, kody (dziedziny kształcenia, PKD, kwalifikacji w ZRK).

W rejestrze na mocy ustawy zostały umieszczone kwalifikacje uregulowane, nadawane w ramach systemu oświaty i szkolnictwa wyższego (pełne i cząstkowe). O umieszczeniu pozostałych kwalifikacji uregulowanych, a więc takich, które mają podstawę w ustawach, decydować będzie minister odpowiedzialny za dany obszar. $W$ rejestrze są też umieszczane tzw. kwalifikacje rynkowe zgłaszane przez zainteresowane podmioty, np. przedstawicieli branż, instytucje szkoleniowe, organizacje zawodowe. Umieszczenie tego rodzaju kwalifikacji w ZRK wymaga odpowiedniego opisania kwalifikacji i przeprowadzenia procesu weryfikacji i nadania kwalifikacji poziomu PRK (Opisywanie kwalifikacji... 2016). Procedura umieszczenia kwalifikacji w rejestrze jest przeprowadzana na wniosek instytucji, która nadaje kwalifikacje. Przykładowo 17.11.2016 r. na wniosek Krajowego Stowarzyszenia Profesjonalistów Rynku Nieruchomości w Ministerstwie Infrastruktury i Budownictwa rozpoczęto procedurę włączenia do ZSK kwalifikacji rynkowej pn. zarządzanie nieruchomościami. Warto podkreślić, że umieszczenie kwalifikacji w ZRK oznacza, że jej wiarygodność i jakość zostały potwierdzone przez władze publiczne, natomiast przypisanie jej poziomu PRK ma umożliwić porównanie tej kwalifikacji z kwalifikacjami nadanymi w innych krajach UE.

\section{KRAJOWE RAMY KWALIFIKACJI DLA SZKOLNICTWA WYŻSZEGO A POLSKA RAMA KWALIFIKACJI}

W Polsce prace nad wprowadzeniem polskiej ramy kwalifikacji trwają od $2008 \mathrm{r}$. Pierwsze etapy tych prac obejmowały opracowanie modelu krajowych ram kwalifikacji (KRK). Ich wprowadzenie w 2011 r. dla szkolnictwa wyższego (Rozporządzenie Ministra Nauki i Szkolnictwa Wyższego z dnia 2 listopada 2011 r.) wymusiło opracowanie programów kształcenia, w tym programów studiów, na podstawie jednolitych zasad opisu zakładanych efektów kształcenia, ujętych w kategoriach wiedzy, umiejętności oraz kompetencji społecznych, i późniejszy opis nadawanych przez uczelnie kwalifikacji z zastosowaniem efektów kształcenia i jednolitego systemu ECTS. Taki sposób opisu kwalifikacji umożliwiał odniesienie dyplomów i kompetencji osób je posiadających do odpowiedniego poziomu europejskiego systemu kwalifikacji. Z tego powodu podobne regulacje zostały przyjęte nie tylko przez kraje Unii Europejskiej, ale też zostały wdrożone lub są wdrażane przez inne państwa, w tym spoza Europy ${ }^{13}$.

Obowiązek tworzenia programów kształcenia na podstawie KRK dla uczelni oznaczał, z jednej strony, autonomię w konstruowaniu programów studiów, a z drugiej strony jednak obowiązek ich opracowania z zachowaniem ściśle określonych zasad. Warto podkreślić, że konieczność opracowania dla każdego kierunku studiów programu kształcenia (zawierającego opis określonych przez uczelnię dla tego kierunku studiów spójnych efektów kształcenia

\footnotetext{
${ }^{13} \mathrm{Nad}$ ramami kwalifikacji pracuje ok. 140 krajów świata, w tym wszystkie kraje Unii Europejskiej - zob. Od kwalifikacji do rejestru (http://www.kwalifikacje.edu.pl/images/download/Publikacje/Od_kwalifikacji_do_rejestru.pdf).
} 
właściwych dla obszaru lub obszarów kształcenia, zgodny z krajowymi ramami kwalifikacji dla szkolnictwa wyższego, a także opis procesu kształcenia prowadzącego do osiągnięcia tych efektów, wraz z przypisanymi do poszczególnych modułów tego procesu punktami ECTS) była dla uczelni trudnym zadaniem. Jego realizacja wymagała przeniesienia uwagi z przebiegu procesu kształcenia na jego efekty. Warto podkreślić, że niewiele było wówczas doświadczeń w tworzeniu programów kształcenia. Pomoc w tym zakresie stanowiły tzw. wzorcowe opisy efektów kształcenia (Rozporządzenie Ministra Nauki i Szkolnictwa Wyższego z dnia 4 listopada 2011 r. w sprawie wzorcowych efektów kształcenia). Były to przykładowe zestawy efektów kształcenia opracowane dla kilku wybranych kierunków studiów, które nie stanowiły wzorów, lecz raczej przykłady dobrych praktyk w budowie programów studiów.

Programy kształcenia, przygotowane na podstawie KRK, i realizowane na ich podstawie procesy kształcenia były elementami oceny i akredytacji jakości kształcenia prowadzonej przez Polską Komisję Akredytacyjną (wcześniej Państwową Komisję Akredytacyjną). W tym okresie zaczął też powszechnie rozwijać się pogląd, że rozbudowa dokumentacji związanej z KRK i zapewnianiem jakości kształcenia ułatwia przeprowadzenie procesu akredytacji. Przyczyniało się to niejednokrotnie do przerostu dokumentacji, której przeznaczeniem było udowodnienie prowadzonych przez uczelnie działań z zakresu jakości kształcenia. Takie podejście stało się podstawą późniejszych zmian, które nastąpiły w zakresie akredytacji.

Wprowadzenie z początkiem 2016 r., w miejsce regulacji dotyczących KRK, przepisów dotyczących polskiej ramy kwalifikacji stworzyło możliwość uproszczenia dotychczas obowiązujących regulacji prawnych dotyczących KRK dla szkolnictwa wyższego. Uproszczenia dokonano jednak w taki sposób, żeby wprowadzenie nowych charakterystyk drugiego stopnia polskiej ramy kwalifikacji nie wymagało od uczelni znacznych prac dostosowawczych. Osiągnięto to, wprowadzając w miejsce dotychczasowych bardzo szczegółowych opisów efektów kształcenia, właściwych dla poszczególnych obszarów i profili kształcenia, syntetycznie sformułowane charakterystyki drugiego stopnia PRK. Dzięki temu kierunkowe opisy efektów kształcenia, opracowane na uczelniach na podstawie poprzednio obowiązujących przepisów, są zgodne z nowymi charakterystykami drugiego stopnia PRK.

Uczelnie, projektując od nowego roku akademickiego (2017/2018) programy kształcenia, w tym programy studiów, muszą jednak opisać efekty uczenia się, zaliczając je w przypadku danego programu kształcenia odpowiednio do charakterystyk poziomów 6-8 PRK. Nie jest to zmiana, którą można nazwać rewolucyjną. Warto podkreślić, że na uczelniach budowa programów kształcenia i zmiany w programach już istniejących stanowią bowiem stały element życia uczelnianego. Nie oznacza to jednak, że zadanie jest łatwe.

\section{PODSUMOWANIE}

Podstawowym założeniem modernizacji systemu kwalifikacji w Polsce jest odnoszenie wszystkich jego elementów do efektów uczenia się. Dotyczy to nie tylko programów kształcenia, lecz także procedur i rozwiązań organizacyjnych przyjętych przez wszystkie instytucje działające $\mathrm{w}$ tym obszarze, w tym podmiotów nadających kwalifikacje oraz oceniających jakość kształcenia i kwalifikacji. Ważnym aspektem jest też walidacja efektów uczenia się, której wyniki w szerszym niż obecnie zakresie powinny być dostępne dla 
zainteresowanych - niezależnie od tego, czy dana osoba nabyła kompetencje w ramach zorganizowanej edukacji czy ucząc się w inny sposób. System ma też, w zakresie szerszym niż dotychczas, umożliwiać gromadzenie oraz przenoszenie (transfer) osiągnięć uczenia się, a tym samym pozwalać na elastyczne dostosowywanie dróg kształcenia się do indywidualnych uwarunkowań osób uczących się. Ma to szczególne znaczenie dla zwiększenia niskiej obecnie mobilności zawodowej Polaków.

W ZSK największą część stanowią elementy, które już istniały; są to m.in. regulacje prawne i dobre praktyki dotyczące opracowywania programów edukacyjnych, przeprowadzania egzaminów, określania efektów uczenia się, ich walidacji, jak też zapewniania jakości tych działań. W dużej części są one zgodne z podejściem proponowanym w ERK. Należy do nich wiele regulacji wprowadzonych w obszarze szkolnictwa wyższego. W Polsce istnieje system instytucji kształcących i nadających kwalifikacje, funkcjonują też podmioty odpowiedzialne za zapewnianie jakości kształcenia i kwalifikacji oraz są opracowane metody ich działania. $\mathrm{Na}$ potrzeby budowy zintegrowanego systemu kwalifikacji są wdrażane też nowe elementy (narzędzia), których celem jest umożliwienie efektywnej integracji całego systemu; najważniejsze z nich to polska rama kwalifikacji oraz zintegrowany rejestr kwalifikacji.

\section{PIŚMIENNICTWO}

Bombiak E. 2013. Kapitał intelektualny przedsiębiorstwa - kluczowy majątek współczesnych organizacji. Zesz. Nauk. Uniw. Przyr.-Hum. Siedl., Administracja i Zarządzanie 96, 71-86.

Chłoń-Domińczak A., Sławiński S., Kraśniewski A., Chmielecka E. 2016. Polska rama kwalifikacji. Warszawa, IBE.

Edukacja i szkolenia 2010. Konkluzje Rady z dnia 26 listopada 2012 r. pt. „Kształcenie i szkolenie a strategia Europa 2020" - rola kształcenia i szkolenia w naprawie gospodarczej, we wzroście gospodarczym oraz w pobudzaniu zatrudnienia. DzU UE z 2012 r., C 393/02.

Europe 2020. A strategy for smart, sustainable and inclusive growth. 2010. Brussels, European Commision, COM (2010) 2020.

Griffin R.W. 2007. Podstawy zarządzania organizacjami. Warszawa, PWN.

Grotowska-Leder J. 2014. Rzecz o kształceniu dorosłych. Lifelong learning w Polsce w perspektywie Unii Europejskiej. Acta Univ. Lodz., Folia Sociol. 20, 117-135.

Haffer R. 2003. Systemy zarządzania jakością w budowaniu przewag konkurencyjnych przedsiębiorstw. Toruń, Wydaw. UMK.

Krajowy Program Reform na rzecz realizacji Strategii „Europa 2020”. 2011. Warszawa, https://www.mr.gov.pl/media/15759/KPR2011.pdf, dostęp: 9.09.2016.

Making a european area of lifelong learning a reality. 2001. Brussels, Commission of The European Communities, $\operatorname{COM}(2001) 678$ final.

Raport referencyjny - aktualizacja. Odniesienie Polskiej Ramy Kwalifikacji do Europejskiej Ramy Kwalifikacji. 2015. Red. S. Sławiński, A. Chłoń-Domińczak. Warszawa, IBE.

Rezolucja Rady w sprawie odnowionej europejskiej agendy w zakresie uczenia się dorosłych. DzU UE z 20.12.2011 r., C 372/01.

Rogowski W. 2006. Kapitał intelektualny jako generator nowych czynników konkurencyjności, w: Kapitał intelektualny. Red. S. Kasiewicz, W. Rogowski, M. Kicińska. Kraków, Oficyna Wydaw.

Rosińska M. 2007. Kapitał ludzki podstawą budowania przewagi konkurencyjnej współczesnych przedsiębiorstw, w: Uwarunkowania budowania konkurencyjności przedsiębiorstw w otoczeniu globalnym. Red. J. Bogdanienko, M. Kuzel, I. Sobczak. Toruń, Wydaw. Adam Marszałek, 11-20. 
Rozporządzenie Ministra Edukacji Narodowej z dnia 13 lipca 2016 r. w sprawie wzorów znaków graficznych informujących o poziomach Polskiej Ramy Kwalifikacji przypisanych do kwalifikacji pełnych i cząstkowych włączonych do Zintegrowanego Systemu Kwalifikacji. DzU z 2016 r., poz. 1022, ze zm.

Rozporządzenie Ministra Nauki i Szkolnictwa Wyższego z dnia 2 listopada 2011 r. w sprawie Krajowych Ram Kwalifikacji dla Szkolnictwa Wyższego. DzU z 2011 r., nr 253, poz. 1520.

Rozporządzenie Ministra Nauki i Szkolnictwa Wyższego z dnia 26 września 2016 r. w sprawie charakterystyk drugiego stopnia Polskiej Ramy Kwalifikacji typowych dla kwalifikacji uzyskiwanych w ramach szkolnictwa wyższego po uzyskaniu kwalifikacji pełnej na poziomie $\mathbf{4}$ - poziomy 6-8. DzU z 2016 r., poz. 1594.

Rozporządzenie Ministra Nauki i Szkolnictwa Wyższego z dnia 4 listopada 2011 r. w sprawie wzorcowych efektów kształcenia. DzU z 2011 r., nr 253, poz. 1521.

Rydzewska-Włodarczyk M. 2006. Kształcenie ustawiczne - istota, cele i formy, w: Dydaktyka w naukach ekonomicznych. Red. T. Kiziukiewicz. Szczecin, AR, 183-191.

Sławiński S., Chłoń-Domińczak A., Szymczak A., Ziewiec-Skokowska G. 2016. Polska rama kwalifikacji. Poradnik użytkownika. Red. S. Sławiński. Warszawa, IBE.

Sławiński S. Omówienie zasadniczych rozwiązań systemowych w ustawie o Zintegrowanym Systemie Kwalifikacji, http://www.kwalifikacje.gov.pl/download/Omowienie, dostęp: 11.11.2016.

Sławiński S., Chłoń-Domińczak A., Kraśniewski A., Pierwieniecka R., Stęchły W., Ziewiec G. 2013. Raport referencyjny. Odniesienie polskiej ramy kwalifikacji na rzecz uczenia się przez całe życie do Europejskiej Ramy Kwalifikacji. Red. S. Sławiński, H. Dębowski. Warszawa, IBE.

Stankiewicz M.J. 2002. Konkurencyjność przedsiębiorstw. Budowanie konkurencyjności przedsiębiorstwa w warunkach globalizacji. Toruń, Wydaw. TNOiK „Dom Organizatora”.

Ustawa z dnia 18 marca 2011 r. o zmianie ustawy Prawo o szkolnictwie wyższym, ustawy o stopniach naukowych i tytule naukowym oraz o stopniach i tytule w zakresie sztuki oraz o zmianie niektórych innych ustaw. DzU z 2011 r., nr 84, poz. 455.

Ustawa z dnia 22 grudnia 2015 r. o Zintegrowanym Systemie Kwalifikacji. DzU z 2016 r., poz. 64, ze zm.

Walczak W. 2010. Analiza czynników wpływających na konkurencyjność przedsiębiorstw. e-mentor 5(37), www.e-mentor.pl, dostęp: 20.11.2016.

Wiatrowski Z. 2012. Edukacja ustawiczna - nadal nieokreślona. Eduk. Ustaw. Dor. 1, 40-43.

Wierżyński W. Kapitał intelektualny - źródło przewagi konkurencyjnej. Portal Innowacji, http://www.pi.gov.pl/ /parp/chapter_86196, dostęp: 10.10.2016.

Wiktorowicz J. 2010. Obraz kształcenia ustawicznego w Polsce na tle pozostałych krajów Unii Europejskiej, w: Podstawy kształcenia ustawicznego od A do Z. Red. M. Znajmiecka-Sikora, E. Roszko. Łódź, Wydaw. EGO, 43-66.

Zalecenie Parlamentu Europejskiego i Rady z dnia 18 grudnia 2006 r. w sprawie kompetencji kluczowych w procesie uczenia się przez całe życie. DzUrz. UE z 2006 r., 962/WE.

Zalecenie Parlamentu Europejskiego i Rady z dnia 23 kwietnia 2008 r. w sprawie ustanowienia Europejskich Ram Kwalifikacji dla uczenia się przez całe życie. DzUrz. UE z 2008 r., C 111/01.

Ziewiec-Skokowska G., Danowska-Florczyk E., Stęchły W. 2016. Opisywanie kwalifikacji nadawanych poza systemami oświaty i szkolnictwa wyższego. Poradnik. Red. S. Sławiński. Warszawa, IBE.

Zintegrowany Rejestr Kwalifikacji, https://www.parp.gov.pl/zintegrowany-rejestr-kwalifikacji-zrk, dostęp: 11.11.2016.

Zintegrowany System Kwalifikacji w Polsce. Materiał przygotowany w ramach projektu „Opracowanie założeń merytorycznych i instytucjonalnych wdrażania Krajowych Ram Kwalifikacji oraz Krajowego Rejestru Kwalifikacji dla uczenia się przez całe życie", https://www.kwalifikacje.gov.pl/download/prezentacja_zsk.pdf, dostęp: 11.11.2017. 